\title{
Legal assistance agencies for children as criminal action victims in criminal justice processes
}

\author{
Dewi Athirah Aksan ${ }^{1}$, Said Karim ${ }^{2}$, Abdul Asis ${ }^{3}$
}

${ }^{1}$ Dewi Athirah Aksan; Fakultas Hukum Universitas Hasanuddin; Perintis Kemerdekaan Street KM 10; Makasar; 90245; Sulawesi Selatan; Indonesia.

${ }^{2}$ Said Karim; Fakultas Hukum Universitas Hasanuddin; Perintis Kemerdekaan Street KM 10; Makasar; 90245; Sulawesi Selatan; Indonesia.

${ }^{3}$ Abdul Asis; Fakultas Hukum Universitas Hasanuddin; Perintis Kemerdekaan Street KM 10; Makasar; 90245; Sulawesi Selatan; Indonesia.

\section{ARTICLEINFO}

\section{Article history:}

Received 2020-09-17

Received in revised form

2020-11-01

Accepted 2020-12-01

\section{Kata kunci:}

Anak Sebagai Korban, Lembaga

Bantuan Hukum, Peradilan

Pidana.

Keywords:

Children as Victims, Legal Aid

Institutions, Criminal Justice.

DOI: https://doi.org/10.26905/

idjch. v11i3. 4249.

How to cite item:

Aksan, D., Karim, M., \& Asis, A. (2020). Legal assistance agencies for children as criminal action victims in criminal justice processes. Jurnal Cakrawala Hukum, 11(3). 313-322. doi:10.26905/ idjch.v11i3.4249.

Corresponding Author:

Dewi Athirah Aksan.

E-mail address: athirahaksan@yahoo.co.id

\section{Abstrak}

Anak-anak yang membutuhkan perlindungan khusus jika berada dalam lingkungan penuh dengan tindak kekerasan atau cenderung tidak peduli. Aspek hukum perlindungan anak perlu diperhatikan karena perlindungan hukum terhadap anak dan peradilan pidana anak merupakan salah satu cara melindungi anak dalam pertumbuhannya di masa depan. Kasus kekerasan terhadap anak yang marak terjadi di Indonesia yaitu tindakan kekerasan sepertipenganiyaan, pelecehan serta tindakan kekerasan seksual. Jenis penelitian yang digunakan adalah penelitian hukum normatif- empirik di Lembaga Bantuan Hukum Makassar, Lembaga Bantuan Hukum Asosiasi Perempuan Indonesia untuk Keadilan Makassar, Lembaga Bantuan Hukum HARS, dan Unit Konsultasi dan Bantuan Hukum Fakultas Hukum Universitas Hasanuddin. Sumber data penelitian ini berupa data primer hasil wawancara dan data sekunder dari studi kepustakaan yaitu menghimpun data-data dan peraturan perundang-undangan, buku-buku karya ilmiah, dan pendapat para ahli. Penelitian menggunakan analisis data secara kuantitatif dengan cara menggabungkan data sekunder yang diperoleh dari studi pustaka. Hasil penelitian ini mengenai bentukbentuk bantuan hukum yang diberikan LBH bagi anak sebagai korban antara lain melakukan pendampingan secara sosiologis, monitoring pemeriksaan di pengadilan, dan pendampingan diversi. Sedangkan optimalisasi pelayanan yang diberikan oleh LBH dalam penanganan anak yang berhadapan dengan hukum dalam hal ini anak korban belum efektif.

\section{Abstract}

Children who need special protection if they are in an environment full of violence or tend not to care. The legal aspects of child protection need to be considered because legal protection of children and juvenile justice is one way to protect children in 


\section{Jurnal Cakrawala Hukum, Volume 11 No. 3 Desember 2020}

ISSN PRINT 2356-4962 ISSN ONLINE 2598-6538

their future growth. Cases of violence against children are rife in Indonesia, namely acts of violence such as abuse, harassment and acts of sexual violence. This type of research is normative-empirical legal research at the Makassar Legal Aid Institute, the Indonesian Women's Association for Legal Assistance for Makassar Justice, the HARS Legal Aid Institute, and the Law Faculty Consultation and Legal Aid Unit at Hasanuddin University. The data source of this research is primary data from interviews and secondary data from literature studies, namely collecting data and legislation, books of scientific work, and opinions of experts. The study uses quantitative data analysis by combining secondary data obtained from literature. The results of this study concerning the forms of legal aid provided by LBH for children as victims included sociological assistance, monitoring of hearings in the court, and diversion assistance. While the optimization of services provided by LBH in handling children dealing with the law in this case the victim's child has not been effective.

\section{Background}

People has the same position before the law without exception which includes the right to be defended (access to legal counsel), treated equally before the law (equality before the law), justice for all. The granting of Legal Aid itself regulated in Act Number 16 of 2011 concerning Legal Aid. The legal aid aims implementation to guarantee and fulfill the right for Legal Aid Recipients to get access to justice. In addition, to realize the constitutional rights of all citizens in accordance with equality principle in law (Raharjo, 2017).

Conceptually, children are initially referred to specifically as Children in Specialistic Circumstances (CEDC) or children who need special protection, that is, if children are in an environment where the relationship between children and those around them, especially adults, is full of acts violence (Suyanto, 2013). Based on the Convention on Child Rights which was ratified by Indonesian government through Presidential Decree Number 36 of 1990, it was also set forth in Law Number 4 of 1979 about Child Welfare and Law Number 35 of 2014 Amendments to Law Number 23 of 2002 about Child Protection, all of which state general principles of child protection are non-discrimination, the best interests of children, survival and development, and respect for children's participation.

Over time, the development of children becoming more mature often occurs various kinds of negative phenomena that disturb their lives. Various social deviations that exist in our society today more and more occur and mostly happen to children. Although the law on protection has been issued (Aqsa, 2015). The sexual violence perpetrators still do the action anywhere, anytime and anyone, especially children. One of them is sexual violence problem. Sexual violence is an important issue to discuss.

Seto Mulyadi, a child observer believes that Indonesian people still often see violence against children as a domestic problem. Therefore, they choose to keep quiet rather than report it. He said that violence against children is not only a matter of government, but also of the general public (Linggasari, 2015). Therefore, the community is expected to not hesitate to report to the authorities when there are children who are abused with their parents.

The issue of legal protection and its rights for children is one of the approaches to protecting Indonesian children. So that the protection of children's rights can be carried out in an orderly, 
and responsible manner, it is needed a legal regulation that is in harmony with the development of Indonesian society (Soetodjo, 2006). The legal aspects of child protection need to be considered because legal protection against children and juvenile justice is one way to protect children in their future growth (Novian, 2015). Legal protection in this case, contains the meaning of protection for children in conflict with the law (ABH). Legal protection for children is an effort to protect the law against various freedoms and children's rights (fundamental rights and freedoms of children) as well as interests related to the welfare of children (Arief, 1998).

Cases of violence against children are rife in Indonesia, namely acts of violence such as abuse, harassment and acts of sexual violence (Purwanto, 2018). This of course becomes difficult because it can damage the mental soul of the child. Of the several acts of violence mentioned earlier, acts of sexual violence that most have a major impact on the mental and mental damage of the child (Novian, 2015). Acts of sexual violence against children are examples of violations of Human Rights (HAM), especially the rights of children (right of child). Facts about the number of cases of sexual abuse affecting children indicate that they tend to get less attention, protection, and are often overlooked (Aryani, 2016).

Law No. 35 of 2014 about Child Protection has provided ample opportunities for a child to grow and develop optimally both physically and mentally so that an ideal generation will be created, but in reality the existing rules do not have a positive impact on children in Indonesia because of the fact that the police are still experiencing obstacles in providing legal protection to victims, which makes sexual violence continue to be against children which causes psychological disruption to children so that children has trauma which causes children's psychology disruption in their growth process and development (Purwanto, 2018). In line with Law No. 23 of 2002 concerning Child Protec- tion which states that child victims of sexual crimes have the right to education about reproductive health, religious values, and moral values, social rehabilitation, psychosocial assistance at the time of treatment until recovery, providing protection and assistance to each the examination level starts from the investigation, prosecution, until the examination at the court hearing (Setyowati, 2010). Article 90 of the Law of the Republic of Indonesia Number 11 Year 2012 concerning the Juvenile Criminal System also stipulates that child victims and witness children are entitled to medical rehabilitation efforts and social rehabilitation, both inside and outside the institution, guaranteeing safety, whether physical, mental, as well as socially, ease in getting information about case developments. Then it is also regulated in Law of the Republic of Indonesia Number 13 of 2006 concerning Protection of Witnesses and Victims which states that there are 13 rights held by a victim, including being free from entrapment questions, getting information about court decisions, getting a new residence and etcetera.

Thus, providing legal assistance to children in conflict with the law, also actually aims to ensure the fulfillment of children's rights so that they can live, develop and participate optimally with humanity dignity, and get protection for the realization of Indonesian children who quality, noble and prosperous (Purwanto, 2018). In addition, handling cases of children, child victims, and / or witnesses children, social counselors, professional social workers and social welfare workers, investigators, public prosecutors, judges, and advocates or other legal aid providers must pay attention to the best interests of the child and work on the atmosphere kinship is maintained (Raharjo, 2017). Based on the background of the problem, the researcher would like to examine more deeply the role of the Legal Aid Institute for Children as Criminal Victims in the Criminal Justice Process in Makassar City. 


\section{Jurnal Cakrawala Hukum, Volume 11 No. 3 Desember 2020}

ISSN PRINT 2356-4962 ISSN ONLINE 2598-6538

\section{Method}

This research type is normative-empirical legal research. Normative research, which is based on law and jurisprudence and empirical research is based on facts obtained in the field. This research conducted at the Makassar Legal Aid Institute, Makassar Women's Association for Justice (APIK) Makassar, Legal Aid Institute, and the Legal Consultation and Legal Aid Unit of the Hasanuddin University Faculty of Law as the fully authorized body in assisting and providing legal assistance to children who are dealing with the law.

Data sources used in this study include primary and secondary data. Primary data were obtained directly at the study from interviews result with parties deemed to have known or mastered the problem to be discussed as well as documents obtained directly from the study site namely Makassar Legal Aid Institute, APIK Makassar Legal Aid Institute, Legal Aid Institute HARS and the Law Faculty Consultation and Legal Aid Unit of Hasanuddin University. While secondary data obtained from literature that is by collecting data and legislation, scientific work books, and experts opinions. This research data collection technique used interviews related to the issues discussed related to Makassar Legal Aid Institute, APIK Makassar Legal Aid Institute, the HARS Legal Aid Institute, and Law Faculty Consultation and Legal Aid Unit at Hasanuddin University. Researchers also use documentation studies by studying documents and archives provided by related parties, in this case the Makassar Legal Aid Institute, the APIK Makassar Legal Aid Institute, the HARS Legal Aid Institute, and the Law Faculty Consultation and Legal Aid Unit of the University Hasanuddin.

The study uses quantitative data analysis combining by secondary data obtained from literature studies, namely by collecting data and legislation, books of scientific work, and opinions of experts with primary data obtained from interviews and documents obtained directly from the research location and then analyzed quantitatively, through a normative approach.

\section{Discussion}

\subsection{Legal Aid Forms provided by Legal Aid Institute for Children as Victims}

Based on Article 5 paragraph (1) provisions of Law Number 16 Year 2011 Regarding Legal Aid, it is determined that the victim receiving legal assistance, whether adult or child, has the right to obtain legal assistance from one or more legal advisors in every victim who faces legal problems. Then the article is also elaborated into Article 89 of Law Number 11 Year 2012 about Criminal Justice System for Children which reads:

“Victim's Children and / or Witness Children are entitled to all the protections and rights stipulated in the provisions of the legislation"

Thus, children with law conflict, child victims, and witness children, must be given legal assistance and accompanied by legal aid providers or legal counsel. Furthermore, in Article 1 number 4 of Law Number 11 Year 2012 about Criminal Justice System fo Children, it is stated that:

"Children who are victims of Crimes, referred to as child victims, are children who have not been 18 years (eighteen years) who experience physical, mental suffering, and / or economic losses caused by criminal offenses. "

Legal assistance forms provided by legal aid institutions provided to children as victims (Victim's Children), include: (a) Providing assistance when the victim's child reports to the Police about the criminal act that they have; (b) Sociological assistance; (c) Monitoring during hearings in court; (d) Provide assistance when diversion is carried out; (e) Assist the victim's child to claim 
the restitution which is the child right if they has suffered a great loss of a criminal offense, both physical and psychological; and (f) Providing counseling services (Sofyan \& Nur, 2016).

Children as victims also have rights are: (a) entitled to legal assistance. As explained in Article 23 paragraph (1) and (2) of Law Number 11 Year 2012 concerning the Criminal Justice System for Children, it is stated that: (1) In every examination, Children must be given legal assistance and be accompanied by a Community Guidance or other companions in accordance with the provisions laws and regulations. (2) At each examination level, the Victim's Child or Witness's Child must be accompanied by parents and / or persons trusted by the victim's child, witness's child, or social worker, (b) has the right to get rehabilitation and safety guarantee.

As explained in Article 90 paragraph (1) letters $a, b$, and c of Law Number 11 Year 2012 concerning the Juvenile Criminal System, it is stated that: (1) In addition to the rights that have been regulated in the laws provisions and regulations referred to in Article 89, child victims and witness children are entitled to medical and social rehabilitation efforts, both inside and outside the institution, guaranteeing safety, whether physical, mental, or social; and ease in getting information regarding case developments. (c) has the right to be referred to related agencies for more specific handling in the recovery context if deemed necessary. As explained in Article 91 of Law Number 11 Year 2012 concerning the Criminal Justice System for Children, it is stated that: (1) Based on the social advisors suggestions, professional social workers, social welfare workers or investigators can refer the child, child victim, or witness child to the institutions dealing with child protection or children's social welfare institutions. (2) in child victim case requiring solving action soon, the investigator, without a social report from a professional social worker, can directly refer the Victim
Child to a hospital or institution that handles child protection in accordance with the Victim's Child. (3) Based on the community research results from the community guidance and social reports from professional social workers or social welfare workers, children, child victims, or witnesses children are entitled to medical rehabilitation, social rehabilitation, and social reintegration from institutions that handle child protection. (4) child victims or witness children who need protection can obtain protection from institutions that handle witness and victim protection or social protection houses in accordance with statutory provisions. (d) Victim's children have special protection right.

As explained in Article 59 paragraph (1) of Law Number 35 Year 2014 concerning Child Protection, it is stated that "The Government, Regional Governments, and other State institutions are obliged and responsible to provide Special Protection to Children". (e) has the right to apply for restitution. Every child as violence victim has the right to submit to court fo having restitution which is the perpetrator responsibility. Restitution is the compensation payment which is charged to the offender based on a court decision that has permanent legal force for material and / or immaterial losses suffered by the victim or his heir. Especially for children who are dealing with the law that is entitled to get restitution is the victim's child. Every child who is a victim as referred to in Article 59 paragraph (2) letter b, d, f, h, I, and j has the right to court in the form of restitution which is the perpetrator responsibility (Supartman, Chess, \& Rini, 2018).

\section{Optimal Services Provided by Legal Aid Institutions}

Several data from Legal Aid Institutions in Makassar City, including Makassar Legal Aid Institute, Legal Aid Institute for the Indonesian Women's Association for Justice (APIK) Makassar, 
HARS Legal Aid Institute, and Consultation and Assistance Unit Law Faculty of Law, Hasanuddin University, the study results will be presented in each sub-discussion.

\section{Makassar Legal Aid Institute}

LBH Makassar is a intitution for marginalized rights / poor communities and law enforcement in South Sulawesi. In handling cases, LBH Makassar consists of several divisions, including: (1) Political Civil Rights Division (SIPOL) which consists of Corruption Eradication \& Judicial Reform Sector, Women's Rights Sector, and the Political Rights and Anti-Violence Rights Division; (2) Division of Economic, Social and Cultural Rights (EKOSOB) consisting of Land and Environmental Rights and Urban Labor and Poor Rights.

In 2019 LBH Makassar received 32 complaints of violence against women and children, a number of victims were women and children with disabilities. As for the forms of violence, it is dominated by 16 cases of domestic violence (domestic violence), and 15 cases of sexual violence (Pratiwi, 2019). The rest is one case concerning violations of the right to a child's identity as shown in Figure 1.

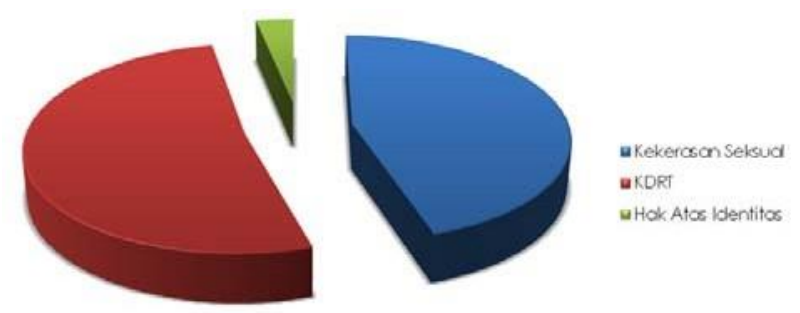

Figure 1. Number of Cases of ViolenceWomen and Children in Makassar Legal Aid 2019

Source: LBH Makassar (2019)

From Figure 1, sexual violence against children in 2019 LBH Makassar received 15 complaints of sexual violence. Complaints about sexual vio- lence received by LBH Makassar have increased in the last three years. An increase in sexual violence reports number through any channel is an indication that more victims are brave enough to report and the public is starting to become aware of this issue. The sexual violence forms based on complaints received by LBH Makassar were in the form of; rape, child molestation / coitus, coercion of marriage, and malicious distribution (Komnas Perempuan, 2019). The categories of victims in- clude girls, girls with disabilities, and women withdisabilities. Based on the place of the incoming sexual violence occurred at school, workplace, community, to the home. In accessing justice for victims there are still similar obstacles because the Draft Law on the Elimination of Sexual Violence (PKS Bill) has not been ratified (Nurjannah, 2016).

The child victims who are victims of sexual violence are fighting for their rights, one of which is the right of restitution where victims are entitled to receive compensation money for the loss of medical and psychological treatment for their recovery after the experience of sexual violence. According to Pratiwi (2019) this is very difficult because some of the perpetrators who commit sexual violence are people who unable and cannot find the compensation, and Pratiwi (2019) believes that LBH Makassar usually takes a stand if this happens, then the restitution is left to State or private institutions that can help fulfill the restitution in this case can be assisted through an application to the Social Institution. However, usually a social institution cannot meet if the amount is large enough (Nurjannah, 2016). And in the end the child victims bear the treatment themselves.

Although the number of cases of sexual violence against women and children has increased every year, but unfortunately the rule of law to ensnare perpetrators who become police references is still very weak, because the rule used by the Police to handle cases of sexual violence is the Criminal Code (KUHP) which its basic formula- 
tion is regulated in a group of moral offenses so that many perpetrators of sexual violence cannot be ensnared because in the Criminal Code there are still many gaps of perpetrators of sexual violence to be free from the bondage of the law, because what is regulated in the Criminal Code is its scope is still limited to rape and sexual abuse (Sain, 2019 ).

\section{APIK Legal Aid Institute}

The APIK Legal Aid Institute is a legal aid organization that focuses on handling cases of women and children relating to Children in Conflict with Law (ABH). LBH APIK Makassar provides legal assistance as perpetrators and children as victims, so there is no exception whether the child is a victim or a perpetrator. Regarding the forms case, LBH APIK is the earliest referral institution for assistance in child cases. LBH APIK also has networks, both government and private that are related to handling $\mathrm{ABH}$ cases so that some cases are referred to by other institutions. LBH APIK Makassar program, among others, school formation for pioneering justice, capacity building for paralegals, new paralegals recruitment, 16day campaign against sexual violence, routine community discussions, meetings of Makassar community and religious leaders, encouraging the establishment of the Law on Sexual Violence, formation of local Makassar city accessibility, cross-institutional FGDs related to sexual violence handling cases, law training for enforcement officers in Makassar city, media roadshows (Koran Fajar, Tribune, Makassar City News, Keker), journalistic training in the perspective of children and women, and law enforcement officials training related Criminal Justice System for Children.

While the stages of LBH APIK's assistance to Victim's Children, namely before conducting assistance. In order to provide assistance, the most important thing is ask the child as victim's accompanied by a parent or guardian, it is necessary to ask whether the need to be assisted after that LBH APIK requires approval from the child's guardian (Sain, 2019). Because in the first stage of assistance, signing a power of attorney by the guardian of the child is then carried out legal assistance, both in the reporting stages to the police, both in the investigation, prosecution and trial. Not only legal assistance, LBH APIK also makes efforts to recover child victims psychology because some cases require the counseling process and psychological recovery of children as victims because sexual violence (Mariani, 2017). Data from LBH APIK Paralegal shows that in 2017 there were no cases of children as victims throughout 2017 but in 2018 there were 3 cases of sexual violence children as victims in which the child was assisted to completion and received his restitution rights assisted by LBH APIK at the reporting stage to police by providing information from psychologists and doctors that this child needs to fight for his right to restitution (Soeltan, 2019).

\section{HARS Legal Aid Institute}

The HARS Legal Aid Institute is a Legal Aid Institute spearheaded by a number of alumni of the Faculty of Law of the Hasanuddin University in 1987 to establish the foundation and office of the LBH HARS to become a meeting place for those interested in the world of law and human rights advocacy. The establishment of this Legal Aid Institute is maximized for community service according to the ideals of its establishment including children as victims. Although the Legal Aid Institute has just been established and no cases have been handled by the HARS Legal Aid Agency regarding children as victims, it opens the door as much as possible if there are children who are dealing with the law coming and ready to help for free (Soeltan, 2019). The assistance form provided is to be able to accompany children from reporting to the police to accompany the victim or the perpetrators to fight for their rights until the 


\section{Jurnal Cakrawala Hukum, Volume 11 No. 3 Desember 2020}

ISSN PRINT 2356-4962 ISSN ONLINE 2598-6538

trial results, if the crime victim has committed immoral acts that cause the child threatened his future will be helped to ask for restitution after proven trial that the perpetrator's guilty. The obstacle is the restitution fulfillment realization because according to it, unlikely that the paying state in this case is responsible for giving restitution to child victims. If the offender is able but cannot provide restitution but has assets, the victim can assist in the case of a decision to confiscate for auction execution, and if the perpetrator does not have property, he believes that is the challenge (Achmad, 2019).

\section{Unhas Legal Consultation and Assistance}

Colleges and universities in Indonesia have legal aid institutions. The implementation of providing legal aid by the University as a scientific institution is basically in scientific practice realization context and charity in carrying out the Tri Dharma in Higher Education, are; (1) Carry out education and teaching, which in this case specifically related to legal aid is education and legal science teaching; (2) Carry out research and development, which in matters related to legal assistance is research and development on various legal issues; (3) Carry out community service, in the providing legal case assistance is service and provide services to the community in a variety of issues relating to law.

Unhas Legal Aid Institute in providing assistance provides legal assistance, mostly assisting the Unhas academic community who are experiencing problems or dealing with the law. And most of the Unhas cases are claims against the Unhas Chancellor at PTUN, so that LBH Unhas is an advocate who defends Unhas. As the Role of Legal Aid Institutions in Handling Children Who Are Confronting the Law (Case Study: 2011-2015 in Makassar City), related to what was investigated by the author, UPT Consultation and Legal Aid Unhas only once in 2015 accompanied ABH.
This assistance is related to the Case "Sexual Harassment by Natural Father Against His Own Children". So the person being accompanied is the Child as a Victim. The victim's child mom is one of faculty employees at Unhas who only reported the incident experienced by her child after feeling a change in her child's behavior. His mother then asked about attitude and behavior change of his child and even checked his child to the doctor. Then evidence was found that his son had been sexually abused and his son told him that his father had committed the crime. So the mother reported her husband to the authorities but at that time it had not been accompanied by the Technical Consultation and Legal Aid Unit. Legal Consultation and Legal Aid Unit in Hasanuddin University accompanied the victim during the trial, because the victim felt pressured by the previous trial so the victim asked to be accompanied, even though there was a public prosecutor demanding the defendant. The victim's reason was not accompanied before because the case was a personal matter and family disgrace (Achmad, 2019).

As for the assistance provided by Technical Consultation and Legal Aid Unit for the Victims of Hasanuddin University, are; (a) Accompanying the meeting with prosecutors or clerks; (b) Communicating with prosecutors; (c) Notifying and explaining the procedures and important matters relating to the case, related to the law and the articles imposed; (d) Monitoring during the trial; and (e) Provide moral support for the victims' families.

Some of the obstacles faced by the Legal Aid Institute in handling children who are dealing with the law in this case Victim Children, include: (1) Lack of law enforcement officers perspective about children and also related to lack understanding of law enforcement apparatus to the SPPA Law so this is very difficult in assistance process, (2) There is no common perception between BAPAS and Legal Aid providers (BAPAS as if acting as a lawyer or BAPAS did not want to hold a defense), (3) 
victims psychology hard to find, (4) Ineffective recovery of $\mathrm{ABH}$, (5) Against cases of sexual harassment for example, mostly hampered because of insufficient evidence, there is no witnesses other than victims, (5) During the witness examination, the legal aid provider was not given information so that the witness was not accompanied by Legal Aid Institution (Law Enforcement did not understand about the witness), (6) Legal Advisers for Victims' Children were not permitted to enter the court, (7 ) Witnesse's words for Victims and law enforcers are different, because of people who have power encouragement, (8) Investigators do not refer to LBH or parents who don't want their children accompanied with family disgrace reasons.

\section{Conclusion}

Based on the research data exposure, the researcher concludes that legal assistance forms provided by legal aid institutions for children as victims include providing assistance when the victim's child reports to the police, about the crime that they have; sociological assistance, monitoring during hearings in court and assisting when diversion is carried out, assisting victim's child to claim restitution rights which if they suffer a large loss of criminal offenses by physical and psychological perpetrators and providing counseling services. Whereas regarding the optimization of services provided by legal aid agencies in handling children in conflict with the law in this case child victims have not been effective, but their handling has been in accordance with Law Number 11 of 2012 about Criminal Justice System for Children and the procedures in Act Number 162011 concerning Legal Aid. As for the obstacles faced so that it is not effective, namely the examination process at each level is still often not supported by special approaches for child victims, such as examinations in special spaces or ethics in taking information. Victim is a disability that has special needs, where there is a need to involve a disability companion in addition to involving a legal assistant.

In court hearings, Supreme Court Regulation No. 3 of 2017 concerning Guidelines for Judging Women's Cases Confronting the Law, is still not widely applied by judges, for example regarding communication in trials with Victims to granting restitution and compensation for victims. In addition, the inadequacy of psychological and physical recovery services in investigating the involvement of psychologists and medical personnel is still limited in proof context. While the examination cost or treatment is still borne by the victim himself, this is exacerbated by the application of restitution or compensation for victims by law enforcement officials which is still low, so this is very difficult in the process of assisting children by Legal Aid Institute.

\section{Rerefences}

Aqsa, Alghifari. 2015. Bantuan Hukum di Wilayah Konflik. LBH Jakarta.

Arief, Barda Nawawi. 1998. Beberapa Aspek Kebijakan Penegakan dan Pengembangan Hukum Pidana. Citra Aditya Bakti. Bandung.

Aryani, Nyoman Mas. 2016. Perlindungan Hukum Terhadap Anak Sebagai Korban Kekerasan Seksual dI Provinsi Bali, E-Journal Bagian Hukum Bisnis Fakultas Hukum Universitas Udayana, Denpasar.

Data dari Lembaga Layanan Perlindungan Perempuan dan Anak seperti P2TP2A Provinsi Sulsel dan Kanit PPA Polrestabes Makassar.

Komnas Perempuan. 2019. Siaran Pers Catatan Tahunan Komnas Perempuan 2019. Diunduh dari https:// www.komnasperempuan.go.id/read-newssiaran-pers-catatan-tahunan-catahu-komnasperempuan-2019\%20.

Linggasari, Yohannie. 2015. Kekerasan Anak di Cipulir SudahSudah Lama Diketahui Tetangga. Diunduh dari https://www.cnnindonesia.com/nasional/ 20150704191437-12-64359/kekerasan-anak-di- 


\section{Jurnal Cakrawala Hukum, Volume 11 No. 3 Desember 2020}

ISSN PRINT 2356-4962 ISSN ONLINE 2598-6538

cipulir-sudah-lama-diketahui-tetangga? pada 1 September 2019.

Mariyani. 2017. Peranan Lembaga Bantuan Hukum APIK dalam Memperjuangkan Hak-Hak Perempuan di Kota Makasar Perspektif Hukum Islam. UIN Alauddin. Makassar.

Novian, Ivo. 2015. Kekerasan Seksual Terhadap Anak, Dampak dan Penangannnya. Sosio Informa Volume 1 No. 12015

Nurjannah, 2016. Peranan Lembaga Bantuan Hukum dalam Penanganan Anak yang Berhadapan dengan Hukum. Unhas, Skrpisi Tidak diterbitkan. Makassar.

Purwanto, Dwi. 2018. Peran LBH Terhadap Kasus Pidana Anak. UMY, Skrpisi Tidak diterbitkan. Yogyakarta.

Raharjo, Trisno \& Laras Astuti. 2017. Konsep Diversi Terhadap Anak Penyandang Disabilitas sebagai Pelau Tindak Pidana dalam Sistem Peradilan Anak. Jurnal Media Hukum UMY. Yogyakarta.

Setyowati, Irma. 2010. Aspek Hukum Perlindungan Anak. Bumi Aksara. Jakarta.

Soetodjo, Wagita. 2006. Hukum Pidana Anak. Refika Aditama. Bandung.

Sofyan, Andi \& Nur Azisa. 2016. Hukum Pidana. Pustaka Pena Press. Makassar.
Supartman, Catur Udi Handayani, Rini Rindawati, 2018. Pendampingan dan Perlindungan bagi Perempuan dan Anak dengan DIsabilitas yang Mengalami Kekerasan. Diiskusi Mendorong Bantuan Hukum bagi Penyandang Disabilitas yang Berhadapan dengan Hukum, 12 Juli 2018. Yogyakarta.

Suyanto, Bagong. 2013. Masalah Sosial Anak. Kencana. Jakarta.

Undang-Undang Republik Indonesia Nomor 16 Tahun 2011 tentang Bantuan Hukum.

Undang-Undang Republik Indonesia Nomor 23 tahun 2002 tentang Perlindungan Anak.

Undang-Undang Republik Indonesia Nomor 13 Tahun 2006 tentang Perlindungan Saksi dan Korban.

Undang-Undang Republik Indonesia Nomor 4 Tahun 1979 tentang Kesejahteraan Anak.

Wawancara dengan Pratiwi, Pendamping Kemasyarakatan dan salah satu paralegal Lembaga Bantuan Makassar di Lembaga Bantuan Makassar tahun 2019.

Wawancara dengan Rachman Soeltan, Direktur Lembaga Bantuan Hukum HARS di Lembaga Bantuan Hukum HARS pada 2019.

Wawancara dengan Rosmiati Sain yang merupakan direktur LBH APIK di LBH APIK tahun 2019. 